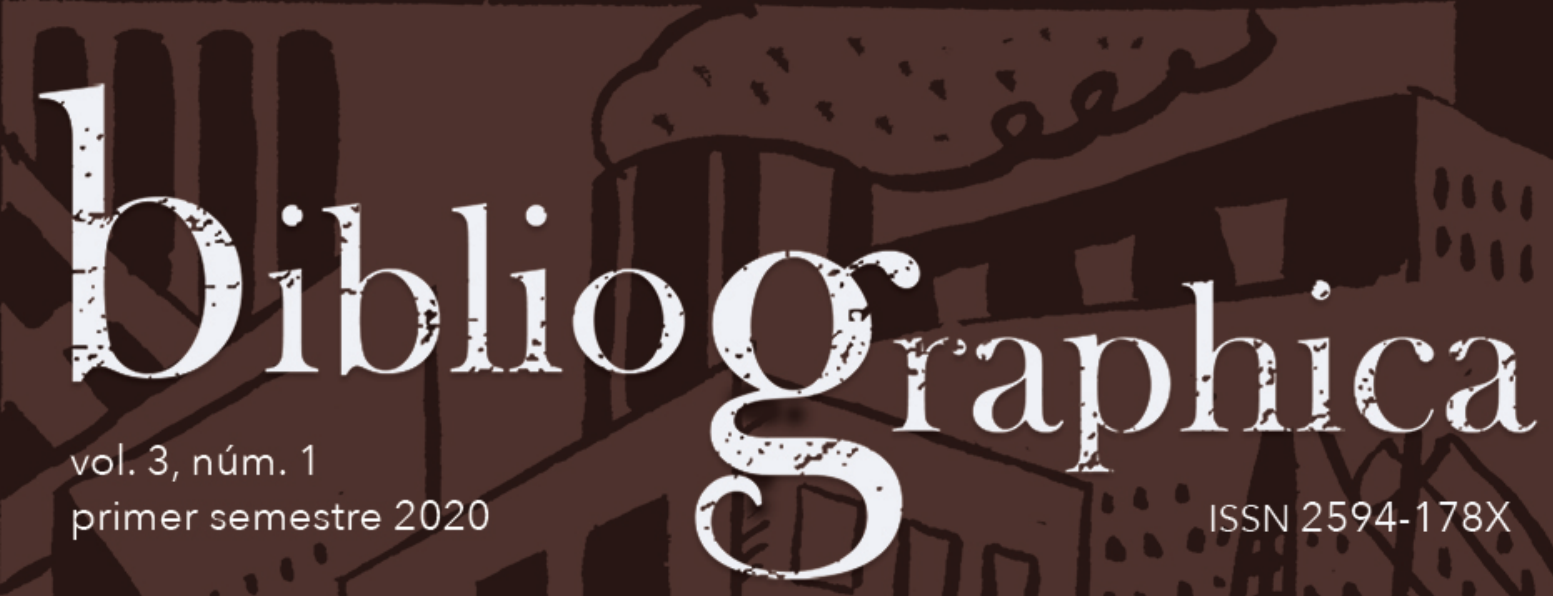




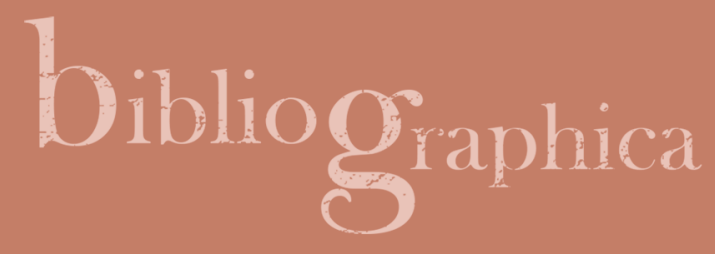

\section{Francisco Villa en la prensa carrancista (1914-1915). La construcción del adversario}

Francisco Villa in the Carrancista Press (1914-1915).

The Opponent's Construction

Francisco Iván Méndez Lara

ivan.mendez.lara@gmail.com

Universidad Nacional Autónoma de México

Posgrado en Historia

Recepción: 27.06.2019 / Aceptación: 09.01.2020

DOI: https://doi.org/10.22201/iib.2594178xe.2020.1.56 
Resumen

Palabras clave

Abstract

Keywords
La imagen de Francisco Villa, uno de los revolucionarios mexicanos más conocidos en el mundo, ha vivido diversas transformaciones en el transcurso del tiempo. Ello se debe a la gran variedad de versiones que existen acerca de su vida, particularmente sobre su pasado de "bandido", las cuales propiciaron el surgimiento de diversas leyendas que él mismo celebró y difundió en muchas ocasiones. Las fotografías, el cine, la historia oral, pero particularmente la prensa, construyeron la imagen de Pancho Villa. Este artículo explica cómo y por qué se construyó la representación del divisionario duranguense en la prensa carrancista publicada en México -opositora a su proyecto revolucionariodurante la lucha de facciones, de finales de 1914 a mediados de 1915; dicho de otra forma, desde la ruptura revolucionaria hasta el triunfo carrancista en las batallas del Bajío.

Prensa carrancista; propaganda; Revolución mexicana; Francisco Villa; lucha de facciones.

The image of Francisco Villa, one of the best-known Mexican revolutionaries in the world, has undergone several transformations over the decades. This is due to the great variety of versions that exist about his life, particularly around his outlaw past, which led to the emergence of various legends that Villa himself, on many occasions, celebrated and spread. The photographs, cinema, oral history, but specially the press, built Pancho Villa's image. This article explains how and why the character of the general from Durango was constructed in the Carrancista press published in Mexico -opposed to its revolutionary project- during the war of factions, that is, since the end of 1914 to the middle of 1915; in other words, from the revolutionary rupture to the Carrancista triumph in the Bajío's battles.

Carrancista press; propaganda; Mexican Revolution; Francisco Villa; war of factions. 


\section{Introducción}

Francisco Villa, Doroteo Arango Arámbula, nacido en La Coyotada, municipio de San Juan del Río, Durango, el 5 de junio de 1878 es -junto con Emiliano Zapata- uno de los personajes más reconocidos de la Revolución mexicana, utilizado continuamente como símbolo de lucha en el imaginario popular. Alrededor de su figura se han creado una serie de versiones y mitos que dificultan la comprensión de su vida y sus acciones. ${ }^{1}$ Su biografía se ha mezclado finamente con un cúmulo de elementos, en especial con la tradición oral, las fotografías, con artículos periodísticos nacionales y extranjeros, al igual que en las imágenes creadas sobre y en torno al revolucionario, tanto en novelas como en películas; Villa incluso firmó un contrato con la Mutual Film Corporation para la filmación de sus batallas. Como bien lo mencionó Friedrich Katz, Villa "estaba enamorado de sus propios mitos e hizo todo cuanto pudo por bordar sobre ellos". ${ }^{2}$ Además, no desconocía en absoluto el poder de la propaganda, mucho menos de la prensa, eje rector de este artículo.

Uno de los medios a través de los cuales se creó y transformó la imagen de Villa fue la prensa de la época, particularmente los periódicos publicados en México durante la lucha de facciones, es decir de finales de 1914 a mediados de 1915, meses decisivos en la resolución del conflicto bélico.

Cabe recordar que al sobrevenir el triunfo del Ejército Constitucionalista, liderado por el Primer Jefe, Venustiano Carranza, sobre Victoriano Huerta, el grupo vencedor sufrió una serie de rupturas y reacomodos que dieron pie a la conformación de dos bandos en pugna: los convencionistas -integrados por villistas, zapatistas y un tercer grupo compuesto por revolucionarios relativamente independientes- y los carrancistas, grupo en el que se encontraban dos de los generales más importantes del periodo, el sonorense Álvaro Obregón y el neoleonés Pablo González. De finales de 1914 a septiembre de 1915 se desarrollaron las batallas más importantes que definieron en gran medida el curso de la Revolución mexicana, primero en el Bajío, después en Aguas-

\footnotetext{
${ }^{1}$ Friedrich Katz ha explicado detenidamente la existencia de tres leyendas en torno a la vida de Villa, sobre todo de sus primeros años: la blanca, la negra y la épica, Pancho ViIla (México: ERA, 2000), I, 15-16; Miguel Ángel Berumen ha estudiado la construcción de la imagen de Villa a través, principalmente, de las fotografías, Pancho Villa: la construcción del mito (México: Océano, 2009).

${ }^{2}$ Katz, Pancho Villa, I, 12.
} 
calientes y finalmente en Sonora, durante un último intento de Villa por derrotar a Obregón. ${ }^{3}$

Acerca de la prensa revolucionaria existen diversos trabajos generales que explican su transformación durante la década armada, ${ }^{4}$ pero los textos particulares sobre el periodo en cuestión son escasos y ninguno se ha enfocado en analizar la transformación de la imagen de Villa en la prensa mexicana durante la etapa mencionada. Al respecto, se han logrado importantes avances, especialmente el trabajo de Mark Cronlund Anderson, influenciado por Friedrich Katz, quien analizó la transformación de la imagen de Villa en la prensa estadounidense entre 1913 y 1916. Asimismo, es importante mencionar el trabajo de Luciano Ramírez Hurtado sobre la Convención revolucionaria, quien esboza en algunos pasajes esta guerra de propaganda entre los bandos en pugna. En el último lustro Gerardo Q. Mendoza y Francisco Méndez Lara han elaborado diversos análisis sobre el papel propagandístico de la prensa carrancista entre 1914 y 1915. No obstante, la revisión específica sobre la imagen de Villa y su transformación en los periódicos de la época no ha sido realizada con detenimiento y, en general, las investigaciones sobre este revolucionario en la prensa son escasas. ${ }^{5}$

\footnotetext{
${ }^{3}$ Sobre el contexto véanse los libros clásicos de Berta Ulloa, La revolución escindida (México: El Colegio de México, 1979), La encrucijada de 1915 (México: El Colegio de México, 1979) y Veracruz, capital de la nación (1914-1915) (México: El Colegio de México / Gobierno del Estado de Veracruz, 1986). Ver, asimismo, Robert E. Quirk, La Revolución mexicana, 1914-1915 (México: Azteca, 1962); Luis Fernando Amaya, La Soberana Convención Revolucionaria, 1914-1916 (México: Editorial Trillas, 1966); Vito Alessio Robles, La Convención Revolucionaria de Aguascalientes (México: INEHRM, 1979); Felipe Arturo Ávila Espinoza, El pensamiento económico, político y social de la Convención de Aguascalientes (México: INEHRM / Instituto Cultural de Aguascalientes, 1991). Ariel Rodríguez Kuri ha elaborado un análisis sobre la lucha de facciones en la capital del país en Historia del desasosiego. La Revolución en la Ciudad de México, 1911-1922 (México: El Colegio de México, Centro de Estudios Históricos, 2010). Recientemente Pedro Salmerón dio a conocer una nueva versión sobre la lucha de facciones en 1915. México en guerra (México: Planeta, 2015).

${ }^{4}$ Un clásico que no puede dejarse de lado es la obra de Diego Arenas Guzmán, El periodismo en la Revolución mexicana, 2 tomos (México: INEHRM, 1967). Un trabajo de gran utilidad cronológica es el capítulo dedicado a la Revolución en Luis Reed Torres y María del Carmen Ruiz Castañeda, El periodismo en México: 500 años de historia (México: Edamex, 2002). Una de las síntesis más completas sobre el papel de los periódicos en la lucha armada es la de Javier Garciadiego, "La prensa durante la Revolución mexicana", en Las publicaciones periódicas y la historia de México (ciclo de conferencias), coord. de Aurora Cano Andaluz (México: UNAM, 1995), 71-88.

${ }^{5}$ Mark Cronlund Anderson, Pancho Villa's Revolution by Headlines (Oklahoma: University of Oklahoma Press, 2000); Luciano Ramírez Hurtado, Imágenes del olvido, 1914-1994. Discurso visual, manipulación y conmemoraciones de la Convención Revolucionaria de
} 
Dicho lo anterior, este artículo tiene por objetivo explicar la forma en que la prensa carrancista utilizó diversas estrategias periodísticas-propagandísticas con el propósito de construir una imagen negativa del principal líder del ejército al que se enfrentaban, Pancho Villa, y así legitimar su propio proyecto revolucionario. ${ }^{6}$ Para ello se analizaron los artículos periodísticos y los editoriales de los principales diarios carrancistas El Pueblo, El Liberal y El Demócrata, ${ }^{7}$ aunque también -con el fin de confrontar algunas versiones- se usaron periódicos con-

Aguascalientes (Aguascalientes: UAA, Centro de Ciencias Sociales y Humanidades, 2010). Sobre la prensa carrancista en Veracruz, Celia del Palacio Montiel, coord., Prensa, revolución y vida cotidiana en Veracruz, 1910-1915 (Xalapa: UV, 2012); Francisco Iván Méndez Lara, "¿Una querella silenciosa? La guerra de papel en los inicios de la lucha de facciones: el caso carrancista (agosto-diciembre de 1914)", Letras Históricas, núm. 10 (primaveraverano 2014): 115-148 y “ ¡Vámonos para Veracruz! La prensa carrancista y su proyecto revolucionario. Del puerto a la Ciudad de México (noviembre 1914 - marzo 1915)", Ulúa. Revista de Historia, Sociedad y Cultura, núm. 24 (2014): 145-176.

${ }^{6}$ A lo largo del trabajo se utilizan las categorías de Jean Marie Domenach respecto a la construcción del enemigo y la exageración, omisión y deformación de la información. En el primer aspecto se establece un "enemigo común" mediante el uso de mitos y elementos maniqueos, ya que no se pelea contra un grupo heterogéneo, sino contra un personaje específico; en cuanto a la segunda estrategia de propaganda, las notas favorables se exageran y los rumores y las mentiras son elementos comunes, pues juegan un papel relevante en el desprestigio del bando contrario. Es importante mencionar que las mismas se encuentran, de una u otra forma, en todas las partes del texto, no son excluyentes y, por el contrario, se complementan entre sí. Jean Marie Domenach, La propaganda política (Buenos Aires: Editorial Universitaria, 1962), 67. Véase la utilización de estas categorías en el caso concreto de las batallas más importantes de 1915 en Francisco Iván Méndez Lara, "La propaganda como arma de guerra en la Revolución mexicana. Las Batallas del Bajío (1915)", Revista Internacional de Historia de la Comunicación, núm. 7 (2016): 67-91.

${ }^{7}$ El Demócrata fue creado y dirigido por el periodista y exmaderista Rafael Martínez, RipRip. En una primera etapa fue itinerante, pues siguió a Carranza en su travesía durante 1913 y 1916; entre 1914 y 1915 se publicó en Veracruz, en donde destacó por su labor propagandística. El Liberal se trató de El Imparcial, el principal diario porfirista, transformado tras la ocupación de la Ciudad de México por los carrancistas en agosto de 1914; fue un periódico de corta duración, pues desapareció a finales del mismo año, entre sus directivos y colaboradores estuvieron Jesús Urueta, Gerzayn Ugarte, Félix F. Palavicini y Ciro B. Ceballos. El Pueblo fue, junto con El Demócrata, un pilar periodístico del carrancismo durante el lustro 1914-1919; se creó tras la ruptura revolucionaria entre carrancistas y convencionistas; entre sus principales administrativos y colaboradores estuvieron José Ugarte, Antonio Revilla, Antonio Rivera de la Torre, Ciro B. Ceballos y Heriberto Barrón. Véase Francisco Iván Méndez Lara, "Venustiano Carranza y la prensa. Un panorama periodístico, 1913-1919". Caleidoscopio. Revista de Ciencias Sociales y Humanidades, núms. 35-36 (2016-2017): 105-110. 
vencionistas como El Monitor y La Convención, ${ }^{8}$ todos ellos consultados en la Hemeroteca Nacional de México en diferentes formatos, desde el físico hasta el digital, pasando por el microfilme.

El presente texto se divide en tres apartados. El primero aborda la "construcción" periodística de Villa como "el enemigo", la representación del grupo contrario y la antítesis del Primer Jefe, Venustiano Carranza. En el segundo se revisa la modificación de ese discurso al arribo de Obregón al Distrito Federal, destacando sus vínculos con grupos del antiguo régimen porfirista. El tercero y último apartado revisa la manera en que Villa fue retratado en la prensa carrancista durante sus derrotas en el Bajío.

\section{La "trinidad maldita" y la primera fase de la propaganda antivillista}

La propaganda carrancista comenzó a conformar una suerte de "leyenda negra" de Villa inmediatamente después de la ruptura revolucionaria que sobrevino tras el triunfo sobre Victoriano Huerta. ${ }^{9}$ El Centauro del Norte fue mostrado como la antítesis de Carranza, versión que se repitió una y otra vez en la prensa adicta al Primer Jefe.

La conformación de una imagen negativa de Villa en la prensa - "la leyenda negra", siguiendo a Katz- no era algo nuevo. A finales de 1910 El Imparcial, principal diario del porfirismo desde el ocaso de la centuria decimonónica, ya lo señalaba como el "célebre bandido" conocido por sus "criminales hazañas". A partir de la primera etapa destacaron su pasado como "criminal despiadado", un mujeriego que no podía controlar sus impulsos y un bandido que no respetaba las leyes. De forma paralela comenzó a esbozarse su figura como el Robin Hood mexicano, el "superhombre" que "estaba por encima de la ley y de la morali-

${ }^{8}$ La Convención fue fundado a mediados de noviembre de 1914 y se caracterizó por ser un periódico itinerante - debido al continuo cambio de sede de la Convención Revolucionaria-, pues fue publicado en Aguascalientes, San Luis Potosí, la capital del país y en Cuernavaca; su director era Heriberto Frías. Al iniciar diciembre de 1914 se creó El Monitor, impreso en las instalaciones de El Imparcial y El Liberal; se trata de un diario poco estudiado y de gran relevancia durante la lucha de facciones; su director fue Luis Zamora Plowes, quien había dirigido el diario villista Vida Nueva, y entre sus colaboradores estuvieron el propio Heriberto Frías, quien a partir de enero de 1915 también fue su director, y el joven Rafael Alducin, que en 1917 fundó el periódico Excélsior. Méndez Lara, "Venustiano Carranza y la prensa...", 111-112.

${ }^{9}$ El País (22 de agosto de 1914): 1, 4. 
dad" debido a que su fin último era el triunfo de la causa revolucionaria. ${ }^{10}$ En el contexto de la rebelión orozquista ya se hablaba de Villa como "el famoso" revolucionario que "tomó parte tan activa en la revolución", que hizo subir al poder a Francisco I. Madero y defendía al régimen en turno de los exrevolucionarios descontentos. ${ }^{11}$

Entre los hombres que comandaba el líder norteño, poseedor de gran carisma, ganó bastante reconocimiento, lo cual propició que en torno suyo se crearan historias fantásticas sobre él y paulatinamente se forjó la idea de la invencibilidad de Villa, versión en la que desempeñó un papel relevante el periodista estadounidense John Reed en su famosa obra México insurgente. La toma de Ciudad Juárez en noviembre de 1913 marcó un antes y un después en la percepción que se tenía de Villa, principalmente en el extranjero. Hugh Scott, comandante de las fuerzas militares alojadas en Fort Bliss, Texas, comparó la proeza del caballo de Troya con la entrada de Villa a la mencionada ciudad fronteriza; más adelante fue el propio Scott quien lo llamó el "Napoleón mexicano". ${ }^{12}$ Dicha idea de invencibilidad se siguió conformando durante el desarrollo de las batallas contra el Ejército Federal que concluyeron con los sonados triunfos en Torreón y en la afamada toma de Zacatecas del 23 de junio de 1914, en donde se dio la ruptura definitiva con Venustiano Carranza, al no acatar sus disposiciones y acusarlo de ser el culpable de la inminente ruptura revolucionaria. ${ }^{13}$ En esta época es importante mencionar que fue al inicio de 1914, con el triunfo en Ojinaga, Chihuahua, cuando Villa comenzó a aparecer con mayor continuidad en la prensa, pues fue este triunfo el que logró expulsar a los federales de aquel estado norteño. Justamente, la famosa fotografía de Villa cabalgando con aires de triunfo tuvo aquí su origen.

En este periodo es posible encontrar la inquietud villista por fundar e impulsar órganos informativos que crearan una imagen positiva de sí mismo y divulgaran su proyecto revolucionario. Para ello creó en 1913 el periódico Vida Nueva dirigido por Silvestre Terrazas y posteriormente por Manuel Bauche Al-

10 John Rutherford, La sociedad mexicana durante la Revolución (México: El Caballito, 1973), 180-181.

${ }^{11}$ El Tiempo (27 de febrero de 1912): 1.

${ }^{12}$ Guadalupe Villa Guerrero, "Pancho Villa en el imaginario popular", en Revolución y exilio en la historia de México: del amor de un historiador por su patria adoptiva. Homenaje a Friedrich Katz, coord. de Javier Garciadiego y Emilio Kouri (México: El Colegio de México / ERA / The University of Chicago / Centro Katz de Estudios Mexicanos, 2010), 403-404.

${ }^{13}$ El periódico El Imparcial aseguró que los rebeldes habían sido rechazados ( 25 de junio de 1914): 1. 
calde, publicación que incluso llegaría a promover una especie de "culto a la figura de Villa", en lo cual sin duda Martín Luis Guzmán también puso importantes cimientos con las Memorias de Pancho Villa. ${ }^{14}$

Desde septiembre de 1914 los órganos informativos carrancistas se concentraron en presentar a un Villa que se guiaba por sus instintos de bandido. Por ello, un elemento propagandístico antivillista común fue señalar que su verdadero nombre era Doroteo Arango, "para recordar que, debajo del glorioso Francisco Villa, se escondía el bandolero y asesino, que se había cambiado de nombre precisamente para escapar a su horrendo pasado". ${ }^{15}$ Villa "era la personificación del mal".

Obregón, quien se había mostrado dudoso respecto a qué bando se uniría tras la ruptura revolucionaria, dio a conocer una hoja volante contra lo que denominó "la trinidad maldita" conformada por Villa, el general Felipe Ángeles y el exgobernador de Sonora José María Maytorena, documento que fue distribuido en Veracruz a finales del mismo año, y a principios de 1915 en la Ciudad de México.

El volante obregonista dio la pauta para que Villa comenzara a ser vinculado directamente con la "reacción" y no sólo se le reprochara su insubordinación y su "negro pasado". Para Obregón "el villismo representaba sin cuestión alguna, la reacción mexicana, era un apéndice de la antigua Contrarrevolución". ${ }^{16}$ El villismo era una suerte de intento por regresar al país hacia la época previa al antirreeleccionismo. Es importante mencionar que una semana más tarde comenzaron a circular las adiciones al Plan de Guadalupe, en donde el propio Carranza aseguró que la reacción estaba encarnada en Francisco Villa.

El documento distribuido por las fuerzas carrancistas en Veracruz desde el 4 de diciembre de 1914 -mismo día que Villa y Zapata se encontraron en Xochimilco- llevó por título "Cargos concretos contra Francisco Villa, José María Maytorena y Felipe Ángeles". ${ }^{17}$ Para el sonorense esta "trinidad" encabezada por Villa exhibía la "intriga, la traición y el asesinato". Obregón buscó exaltar los sentimientos populares, con base en la difamación de los tres revolucionarios: "El abnegado pueblo, que nunca ha economizado sangre para castigar a los traidores, dará esta vez prueba de civismo y honradez, apartándose de estos tres genios

\footnotetext{
${ }^{14}$ Katz, Pancho Villa, I, 322; II, 50-51.

15 lbid., II, 45.

16 José C. Valadés, Historia general de la Revolución mexicana, 5 tomos (México: SEP / Gernika, 1985), IV, 166.

${ }^{17}$ Apareció por primera vez en El Pueblo (11 de diciembre de 1914): 1.
} 
del Mal, sin olvidar que es preferible morir protestando contra la maldad, que vivir pactando con ella".18 Sin lugar a dudas, la postura de Obregón se inserta en el momento en que las fuerzas revolucionarias estaban en plena reorganización, las certezas prácticamente no existían y era necesario quitar hombres al enemigo, además de despistar a posibles seguidores de los convencionistas. En ese momento ambos bandos contaban con posibilidades similares para triunfar, pero lo que comenzó a diferenciar, periodísticamente hablando, al grupo carrancista del convencionista fue la radicalidad de su propaganda, que si bien no tuvo un impacto directo en el desarrollo de las batallas, sí les permitió crear un discurso propio de legitimación.

El manifiesto, en la parte referida a Villa, estaba compuesto de 15 puntos, en los que Obregón puso atención a tres temas: homicidios e intentos de asesinato, las "traiciones" del duranguense y su ambición personal. En el primer rubro nombró el supuesto intento de asesinato de Madero en Ciudad Juárez, "iniciando con este acto su vida de traiciones"; el aparente homicidio del diputado maderista Enrique García de la Cadena, así como exaltar el polémico caso del inglés William S. Benton, entre otros casos que incluían a algunos de sus propios hombres.

En el segundo rubro, el autor enlistó las ocasiones en que Villa se había insubordinado. Había pretendido, en primer lugar, "traicionar al traidor Victoriano Huerta, cuando éste era aun leal al Gobierno del señor Madero, y hacía la campaña contra el orozquismo"; ${ }^{19}$ después, el desconocimiento que hizo al Plan de Guadalupe, tras lo cual intentó invitar al propio Obregón a sumarse a la traición "ofreciéndole la Primera Jefatura del Ejército, y haberlo mandado asesinar posteriormente porque éste se negara a secundar su traición dando la orden para su ejecución, primero en Chihuahua, por segunda vez en Corralitos, y por tercera vez en Gómez Palacio...."20 Al mismo tiempo, por fomentar la traición del "ex gobernador" de Sonora, José María Maytorena. Finalmente, destacaba el apoyo que recibía de la reacción, como lo demostraba su Manifiesto a la Nación del 24 de septiembre de 1914, al tener en sus filas a muchos exfederales y científicos; Obregón incluso señaló que Villa había enviado un telegrama al exgeneral federal José Refugio Velasco, para evitar la entrada de las filas constitucionalistas a la Ciudad de México.

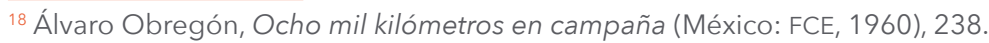

${ }^{19}$ Ibid., 233.

20 lbid., 234.
} 
A los intentos de homicidio, asesinatos y traiciones, el sonorense agregó los actos realizados por el general de la División del Norte para llenar su bolsillo: haberse apoderado "por la fuerza bruta" de "cinco millones de pesos de la Tesorería General de la Nación; de más de doscientos mil de la oficina impresora de billetes constitucionalistas, y haber ordenado la aprehensión del señor Serapio Aguirre, Tesorero General de la Nación, obligándolo a firmar una cheque por cuarenta y un mil dólares, que tenía depositados la Primera Jefatura en el First National Bank, de El Paso, Tex.". Agregaba, asimismo, el impulso que Villa había dado a los juegos de azar en todos sus dominios, para favorecer a sus familiares. ${ }^{21}$

La Convención y El Monitor, prensa convencionista, no mencionaron en ese momento la hoja volante de los cargos concretos contra Francisco Villa, pero sí llevaron a cabo una labor de desprestigio en contra de los carrancistas. Ambos diarios aseguraron que desde que Venustiano Carranza se había mudado con sus hombres a Veracruz, sólo habían lanzado injurias contra la Convención. Se dieron a la tarea de relatar la forma en que los carrancistas se dedicaban a sembrar la "discordia" dentro de la Junta Revolucionaria. Sin embargo, las críticas no solamente estaban dirigidas a las actitudes de Carranza, sino sobre todo contra el "traidor" Obregón, quien unos días antes había firmado la bandera mexicana y asegurado que siempre combatiría al que se rebelara contra la Convención. El sonorense, según la prensa provillista, "fue el primero en rebelarse contra la Convención" 22 e impulsar a los ejércitos carrancistas para combatir a sus antiguos compañeros.

No obstante, las críticas contra los carrancistas - que parecían abrir una brecha para futuros enjuiciamientos- fueron casos aislados en esta primera etapa, ya que generalmente no dedicaron muchas páginas al desprestigio del Primer Jefe ni de Obregón en publicaciones posteriores, principalmente porque consideraban que las fuerzas revolucionarias continuarían su proceso de reacomodo, y velaron por la reconciliación revolucionaria.

La hoja volante de Obregón ha sido el ejemplo más evidente para la historiografía, ya que fue publicada en su libro Ocho mil kilómetros en campaña, una vez que los carrancistas derrotaron a los convencionistas. No obstante, la campaña se había presentado desde meses atrás en los principales diarios adictos al Primer Jefe, El Pueblo y El Liberal.

${ }^{21} \mathrm{lbid}$.

${ }^{22}$ La Convención, "Al margen de la Convención. El sargento Obregón" (5 de enero de 1915): 2. 
Los carrancistas se enfocaron en crear una figura que representara lo contrario a la visión revolucionaria, con la que pudiera contrastarse lo llevado a cabo por Venustiano Carranza y sus hombres cercanos. La repetición de los mensajes "bajo diversos aspectos" y a través de varios testimonios fue una constante en el último trimestre de $1914 .^{23}$

Para mostrar lo "bajo" que resultaba el proyecto villista, se echó mano de la publicación de un manifiesto redactado por un viejo correligionario de Villa, el general Maclovio Herrera, quien se había unido al carrancismo y luchaba contra Felipe Ángeles en el norte, al lado del general Antonio I. Villarreal. El 6 de diciembre, día en que Villa y Zapata llegaron a la Ciudad de México, El Pueblo publicó "Francisco Villa exhibido de cuerpo entero. Manifiesto a la nación lanzado por el Señor Gral. M. Herrera".24

El periódico transcribió completo el manifiesto del exgeneral villista; aseguraba que su punto de vista merecía tomarse en cuenta debido a que había peleado al lado de Villa en todas las batallas de la División del Norte, a lo largo de la revolución constitucionalista. Herrera afirmaba que Villa nunca había ganado ninguna batalla y que todo se debía a la "astucia de sus jefes de Brigada, de la oficialidad y de los soldados". Continuaba el texto con la siguiente aseveración: "Tu nombre es DOROTEO ARANGO, inscrito ya varias veces en los registros de las prisiones de Chihuahua por delitos que las leyes castigan con la horca; es bien conocido en las poblaciones de la sierra de Chihuahua y Durango, que fueron durante muchos años el teatro de tus fechorías de ladrón de camino real y de asesino desalmado". ${ }^{25}$

Una vez subrayados los antecedentes de Villa como "ladrón", Herrera termina su texto con un llamado al pueblo para que combatiera "al personaje que conjugaba todos los males de la república: no hay que vacilar si no queremos la ruina de la revolución y de la Patria; dejémonos de perseguir curas y monjas; Villa: he allí al enemigo".

Además de las opiniones de Herrera, los periódicos carrancistas rescataron los testimonios de periodistas carrancistas de la talla de Félix F. Palavicini, Heriberto Barrón, Rafael Martínez Rip-Rip y Ciro B. Ceballos. Este último publicó un editorial titulado "Los inquisidores del Villismo", en el que levantaba una serie de cargos contra el Centauro del Norte, a quien culpó de provocar la fractura

${ }^{23}$ Domenach, La propaganda política, 59.

${ }^{24}$ Maclovio Herrera, "Francisco Villa exhibido de cuerpo entero", El Pueblo (6 de diciembre de 1914): 5.

${ }^{25}$ Ibid. Las mayúsculas son del original. 
en el seno revolucionario y lo señaló como el iniciador de la guerra que apenas comenzaba. ${ }^{26}$

Por su parte, Rafael Martínez mostró en un editorial "la regularidad histórica" con que las "traiciones" al país ocurrían. Para Rip-Rip "el Caso Villa" no era algo nuevo, sino que ocurría cuando una lucha armada parecía estar terminada. Criticaba la actitud del jefe de la División del Norte debido a que, por sus "decisiones indebidas y reprochables", terminó con la tranquilidad pasajera que vivía el país. Para dicho autor el futuro inmediato quedaba en manos de Villa, la paz dependía de que abandonara las armas, pues "un paso salvaba o hundía, absolvía o condenaba". ${ }^{27}$

Palavicini, entonces secretario de Instrucción Pública, redactó un editorial antivillista titulado "El crepúsculo de los dioses", donde atacaba a los periódicos villistas que distorsionaban los acontecimientos y mostraban otra cara del traidor. Palavicini repetía gran parte de la argumentación de sus compañeros carrancistas, pero añadía que Villa había utilizado una gran cantidad de dinero para construir una imagen favorable, en México y en el extranjero. La prensa villista, aseguraba Palavicini, narró las batallas de Ojinaga, Torreón, Zacatecas, y "los grandes diarios americanos, comprados espléndidamente por Sommerfield, dieron a Francisco Villa la fisonomía napoleónica, sin que una vez citaran al verdadero general de esas victorias: Maclovio Herrera".

A diferencia de Villa, Carranza no había alquilado "cantores" y había reconocido los triunfos y el "talento estratégico" de Obregón, Pablo González, Manuel M. Diéguez, Antonio I. Villarreal, Salvador Alvarado, Francisco Coss y Francisco Murguía. ${ }^{28}$ El autor destaca que el prestigio personal era insignificante, lo que importaba era la revolución social. El texto concluye de forma llamativa: "Carranza sabe que los dioses han muerto; que, concluida la comedia, no queda sino la sonrisa en los labios del espectador y, esto pensando, no se ha dedicado a hacer la escultura de su personalidad política, sino a sembrar la simiente para que la patria coseche los beneficios [...]. La escuela egoísta ha muerto, en el crepúsculo de los dioses". 29

No debe olvidarse que los diarios carrancistas -además de elaborar una imagen negativa de Villa- difundieron de forma paralela el proyecto revolucio-

${ }^{26}$ Ciro B. Ceballos, "Editorial. Los inquisidores del Villismo", El Liberal (25 de noviembre de 1914): 3.

${ }^{27}$ Rafael Martínez, "El Caso Villa", El Liberal (26 de octubre de 1914): 3.

${ }^{28}$ Félix F. Palavicini, "El crepúsculo de los dioses", El Pueblo (2 de diciembre de 1914): 2.

$29 \mathrm{lbid}$. 
nario impulsado por el Primer Jefe, contrario al de la Convención, cuya principal bandera era el Plan de Ayala zapatista. Por ello, desde que Carranza arribó a Veracruz ordenó que los periódicos dieran difusión a su proyecto revolucionario, y El Pueblo fue el principal propagador de los planteamientos y reformas sociopolíticas carrancistas. ${ }^{30}$ Este periódico se dio a la tarea de arrebatar la bandera social a los ejércitos convencionistas y en sus páginas afirmó que los principales objetivos de la revolución carrancista eran la redención del obrero y la legislación agraria.

A partir de la segunda quincena de diciembre la prensa carrancista difundió en cada uno de sus números el proyecto de reformas políticas, económicas y sociales carrancistas vertidas en las adiciones al Plan de Guadalupe -plan del 26 de marzo de 1913 que sólo trataba cuestiones de índole política-, dadas a conocer por Carranza el 12 de diciembre de 1914. En el artículo 2o. de dichas adiciones se asentaron las propuestas sociales más importantes, que incluían la creación de leyes agrarias y el mejoramiento de las condiciones de trabajo de las clases proletarias. Para distribuir estas propuestas, en El Pueblo se insertó del 24 de diciembre de 1914 al 19 de enero de 1915 una columna -en varias ocasiones en la primera plana- intitulada "Programa de la Revolución Social encabezado por el C. Don Venustiano Carranza", que explicó punto por punto el proyecto carrancista. Es decir, la construcción del enemigo iba de la mano con el impulso de un proyecto revolucionario, no era algo gratuito. ${ }^{31}$ La construcción de la "leyenda negra" de Villa y del villismo cobró gran fuerza durante la toma de la Ciudad de México por parte de Obregón, lo cual corresponde a una segunda fase dentro de la "construcción" de Villa y del villismo como enemigos carrancistas.

\section{II. "El Napoleón bandido", marioneta del antiguo régimen}

La prensa y la propaganda no podían, ni pueden, partir de cero para imponer cualquier idea en un momento específico. "Por regla general, la propaganda opera siempre sobre un sustrato preexistente, se trate de una mitología nacional [...] o de un simple complejo de odios y de prejuicios tradicionales". ${ }^{32}$ Lo anterior ocurría por medio de la palabra y de ciertas asociaciones de índole

\footnotetext{
${ }^{30}$ Arenas Guzmán, El periodismo en la Revolución, I, 272-273.

${ }^{31}$ Méndez Lara, "¡Vámonos para Veracruz!...", 148, 150-151, 153.

32 Domenach, La propaganda política, 67.
} 
"emocional" con el enemigo que se estaba creando al calor de la guerra. Pancho Villa fue analizado por la prensa carrancista, su mito y su pasado fueron hechos uno mismo, paulatinamente lo fueron concibiendo como amigo de los máximos enemigos del pueblo, de los "científicos", del clero, de la burguesía, incluso de Díaz y de Huerta: Villa era la marioneta que jamás habían podido imaginar. La toma de la Ciudad de México por Obregón a finales de enero de 1915 resultó fundamental para la construcción de la imagen de Villa, así como para la difusión dada a las metas del carrancismo.

La relación de Villa con las fuerzas del antiguo régimen resultó un tanto ambigua, puesto que si bien es cierto que Carranza se rehusó a absorber a los exfederales, Villa lo hizo, pero no de una forma desmesurada como lo afirmó la prensa carrancista. Posiblemente el líder de la División del Norte los aceptó en sus filas por la influencia que tuvo sobre él un exfederal, Felipe Ángeles, además de la necesidad de hacerse de técnicos y expertos en el ámbito militar, como lo había hecho con Federico Cervantes desde 1913. ${ }^{33}$ En cuanto a Villa y la Iglesia, el duranguense nunca mostró repulsión hacia la religión sino hacia los curas, que "solían aprovecharse de la ignorancia y la necesidad de la gente". ${ }^{44}$ Un cura, creía Villa, no podía ser la representación de Dios en la tierra.

La prensa carrancista puso el acento en la anexión de elementos del exejército federal a las tropas villistas, por lo que La Convención publicó que sólo se unieron los elementos que pudieran "comprobar su ninguna participación en los acontecimientos de febrero y que durante la usurpación no hayan servido cargos ni cometido actos de iniciativa personal contra la revolución", y se reconoció la labor de Villa ante la crítica situación que vivía aquella oficialidad. En entrevista con Roque González Garza, encargado del poder ejecutivo, afirmó que era "torcida" la interpretación que los periódicos carrancistas habían dado a los actos y a las palabras de Villa, pues nunca se había pensado en la reorganización del Ejército Federal, que había sido "el enemigo inmediato con que se tuvo que enfrentar el grupo de ciudadanos armados". ${ }^{35}$ El Monitor siguió la misma línea, al asegurar en su primera plana: "La revolución admite en su seno la parte sana de lo que se llamó ejército federal". ${ }^{36}$

El 12 de enero de 1915, Félix Palavicini explicó en El Pueblo lo que le pareció una de las grandes contradicciones de Villa, quien siempre solía proclamar

\footnotetext{
${ }^{33}$ Katz, Pancho Villa, II, 23.

${ }^{34} \mathrm{lbid}$., 24.

${ }^{35}$ La Convención, "No se reorganizará el Ejército Federal" (6 de enero de 1915): 1.

${ }^{36}$ El Monitor (5 de enero de 1915): 1.
} 
su amor al "pueblo y a las clases humildes": ayudar e incluso beneficiar a las clases conservadoras. Palavicini subrayó de forma sarcástica la forma en que Doroteo Arango aceptó a los exfederales en su ejército "porque al fin todos somos hermanos y el pasado es pasado", citó en su columna en El Monitor del 5 de enero, cuando Villa incluyó dichas fuerzas. El duranguense, junto con las fuerzas reaccionarias en un "gobierno fragmentado" como lo era la Convención, se trataba -para Palavicini- del reflejo de la negativa villista por modificar la situación vivida en el antiguo régimen. La mentira de que Villa tenía en mente una amplia reforma social, aseguraba el autor, "pudo conservarse mientras los hechos no han desmentido a las palabras y ahora que en las filas constitucionalistas, los generales participan a restituir a los pueblos sus ejidos, a devolver, con la ley en la mano, a los labradores la tierra de sus antepasados", con ello el periodista carrancista aseguró que se confirmaba que el pueblo encontraba con Carranza "a sus amigos y allá con Villa sus enemigos de ayer, de hoy y de mañana. La reacción tiene con VILLA LA MÁSCARA DEL DIABLO". ${ }^{37}$

El Pueblo señaló que, tras revisar la prensa de la Ciudad de México, se percataron de que el criterio del villismo, disfrazado de Convención, distaba mucho de las aspiraciones carrancistas, que eran "diametralmente opuestas". La simple posibilidad de que se integraran al ejército villista los antiguos "militares porfiristas", fue exaltada y descalificada. "En el villismo encontramos los caracteres todos de las dictaduras: el espíritu de absorción, la tendencia centralizadora, la confianza en el Gobierno de un fuerte absoluto que manda y muchos débiles que obedecen". ${ }^{38}$ Se insistía en que los hechos sólo mostraban que el conflicto entre villistas y carrancistas no se trataba de una simple lucha entre "hermanos distanciados por diferencias transitorias", pues unos sólo buscaban reducir la libertad y los carrancistas ensancharla. Uno de los dos bandos debía ser aniquilado; en el fondo, Palavicini aseguró que la lucha era entre la democracia versus la dictadura.

Mientras la Convención permaneció en Cuernavaca, Morelos, donde se había trasladado tras el arribo de Obregón a la Ciudad de México a finales de enero de 1915, la propaganda provillista nunca se detuvo $y$, pese a estar en territorio netamente zapatista, lugar en que se dividieron paulatinamente los delegados del norte y sur, Villa, como el brazo armado del movimiento convencionista, siempre fue exaltado y confrontado con la personalidad del Primer Jefe.

\footnotetext{
${ }^{37}$ Félix F. Palavicini, "Las máscaras del Diablo", El Pueblo (12 de enero de 1915): 3. Las mayúsculas son del original.

${ }^{38}$ Jorge Useta, "Al margen de los sucesos diarios", El Pueblo (13 de enero de 1915), 3.
} 
Entre el 14 y el 17 de febrero La Convención publicó en una columna titulada "Hechos y razones contra las calumnias de A. Obregón", la refutación de algunos de los cargos concretos que Obregón había lanzado a Villa a finales de noviembre y principios de diciembre de 1914; sus autores fueron Francisco Lagos Cházaro y el teniente coronel Juan Antonio Acosta. Punto por punto el manifiesto obregonista fue "desmentido" por el futuro encargado del poder ejecutivo de la Convención. Según los autores, Villa nunca quiso matar ni a Madero ni al diputado Enrique García de la Cadena; en el caso Benton afirmaron que el Centauro no lo había asesinado. Se subrayó el maderismo de Villa, quien siempre respetó a Madero durante su vida, "nutrió su credo en los principios revolucionarios del apóstol, envolvió su recuerdo en una dulce leyenda de amor, fue y continúa siendo maderista". ${ }^{\prime 9}$

Además, Obregón fue criticado por su afirmación respecto al Manifiesto lanzado por Villa en septiembre de 1914, y su supuesta insubordinación. De forma paralela, el texto señaló que había sido el propio Obregón quien se había ofrecido en varias ocasiones a Villa para traicionar al Primer Jefe. Los autores sentenciaban su artículo afirmando que Obregón ni siquiera sabía leer con atención, y por ello modificaba todas las versiones. ${ }^{40}$

Ante el incremento de las notas que exaltaron a Villa, la prensa adicta a Carranza publicó un editorial de Alfonso Herrera titulado "Carranza o Villa y Zapata", donde una vez más repetían los argumentos que ya han sido analizados, no obstante, en este artículo los reaccionarios eran parte fundamental del supuesto poderío villista: todos los enemigos de la patria y, por ende, de la Revolución, estaban con Villa: "hay en el actual movimiento tres hombres: CARRANZA-Villa-Zapata. El primero como el redentor moderno dispuesto a redimir un pueblo, pero jamás dejarse crucificar por los sicarios, ni permitir que se ultrajen los intereses nacionales. Llegará hasta lo inconcebible, pero jamás cederá un ápice a los malvados". Ni Zapata con su Plan de Ayala podría hacerle sombra a la Ley Agraria del 6 de enero de 1915 ni Villa -con quien se agrupaban las "castas privilegiadas", los "soldados vencidos y mercenarios", los "traicioneros"- podrían siquiera compararse con Carranza, quien era descrito como "redentor de los derechos", el hombre de la legalidad pues, afirmaba Herrera: "Su Programa es lo que necesitamos, y cuando se implante hasta su omega,

\footnotetext{
${ }^{39}$ Francisco Lagos Cházaro y Juan Antonio Acosta, "Hechos y razones contra las calumnias de A. Obregón", La Convención (16 de febrero de 1915): 2.

40 lbid.
} 
entonces aun cuando sea en el futuro sabrá México estimar hasta dónde pudo llegar la visión de ese hombre vidente y singular. Hoy él es necesario. Debe consumar la obra más grande que nuestra historia patria ha recogido". ${ }^{41}$

En marzo apareció una importante cantidad de notas que vinculaban a los convencionistas y, específicamente, a los villistas con la reacción. El Pueblo aseguró en un editorial intitulado " $\mathrm{i} \mathrm{O}$ ellos o nosotros!" que el general Felipe Ángeles estaba buscando reagrupar el antiguo ejército federal, "los que sirvieron contra Madero y contra Carranza", a través de un manifiesto. Ángeles era, pues, "amigo" de los "cómplices de Huerta" y su lugar debía estar con quienes no persiguen la realización de la Revolución. La clase militarista estaba no sólo con el exfederal que había traicionado a Carranza durante la revolución constitucionalista, sino también con Villa; uno los reorganizaba, el otro los animaba para "azotar" al pueblo: "Que Ángeles reorganice el ejército federal; que Villa lo proteja bien está. La reacción juntará todos sus elementos, reunirá todos sus afines y acopiará todas sus fuerzas. Si triunfamos habremos vencido para siempre". ${ }^{22}$ El militarismo, viejo enemigo de los liberales y sinónimo de "opresión y regímenes absolutistas", estaba del lado de Villa. En marzo, la repetición fue usual en las páginas de El Pueblo: "los reaccionarios del Norte y del Sur de la República, en criminal consorcio con los soldados del cuartelazo y la usurpación, luchan desesperadamente por resucitar los fatídicos tiempos de los fueros y privilegios; tiempos malditos en que un grupo privilegiado era dueño absoluto de las conciencias, del honor y de los intereses del pueblo".43

El clero también estaba del lado de Villa, al que describió la prensa carrancista como "opositor de Madero" (y coautor del cuartelazo), cómplice de Huerta y "azuzador de Villa e inspirador de Ángeles". ${ }^{44}$ En marzo de 1915 en El Pueblo se publicó una nota editorial que puso énfasis en la "intransigencia" del Primer Jefe, ya que aseguraba que éste no aceptaría a ningún hombre que estuviera contra los ideales revolucionarios, como el clero o los exfederales. ${ }^{45}$

Es importante mencionar que en febrero de 1915, mientras todas estas notas relacionadas con el clero aparecían en los periódicos carrancistas, Obregón publicó diversos decretos con el objetivo de obtener mayores recursos para la

\footnotetext{
${ }^{41}$ Alfonso Herrera, "Carranza o Zapata y Villa", El Pueblo (8 de marzo de 1915), 3. Las mayúsculas son del original.

42 El Pueblo, "O ellos o nosotros" (20 de marzo de 1915): 3.

${ }^{43}$ lbid., "Las tempestades de la libertad y la tranquilidad sepulcral" (27 de marzo de 1915): 3.

${ }^{44}$ Ibid., "El cura de la ciudad y el cura de aldea" (22 de marzo de 1915): 3.

45 Ibid., "Editorial. La intransigencia del señor Carranza" (24 de marzo de 1915): 3.
} 
guerra. El primero que se implementó, y uno de los más polémicos, forzó al clero a contribuir con de medio millón de pesos para la Junta de Auxilios al Pueblo. El canónigo Antonio de Jesús Paredes se negó y fue aprehendido junto con otros 167 sacerdotes, aunque sólo 15 fueron enviados a Veracruz en pésimas condiciones. ${ }^{46} \mathrm{El}$ anticlericalismo del carrancismo no solamente quedó plasmado en las notas periodísticas.

El fortalecimiento de los embates contra Villa y la Convención se buscó a partir de la comparación entre Carranza y Benito Juárez, además de que la prensa carrancista hizo una analogía entre los procesos revolucionarios de la Guerra de Reforma o de los Tres Años y la guerra contra Villa en $1915 .{ }^{47}$ Carranza era el nuevo Juárez.

\section{El "tigre domado", las derrotas en el Bajío}

En el transcurso de los siguientes meses, durante las batallas en Guanajuato, la prensa carrancista continuó haciendo labor de desprestigio contra Villa, pero cabe destacar que la característica de "invencibilidad" de Villa en el campo de batalla fue retomada en esta nueva etapa para fortalecer la construcción del adversario.

Los partes de guerra de Obregón de la primera batalla en Celaya, Guanajuato, que se desarrolló del 4 al 6 de abril de 1915, fueron reproducidos en El Pueblo y aseguraban que los villistas habían sido aniquilados. Dicho diario señaló que las cargas de caballería de Villa, sin planteamiento táctico, habían sido detenidas por Obregón. Asimismo, aseguró en un encabezado que afortunadamente Villa dirigía la acción; por su parte, El Demócrata destacó la cobardía del "Napoleón bandido" al huir del lugar. ${ }^{48}$ En los días previos al segundo enfrentamiento en Celaya, la prensa carrancista remarcó aquella construcción y relación que había desarrollado a lo largo de los meses anteriores: no se estaba venciendo a Villa, sino al "alma de la burguesía", de la Iglesia, de los yankees, se exterminaba a los últimos baluartes de la reacción. El triunfo era del pueblo, de

${ }^{46}$ Linda B. Hall, Álvaro Obregón. Poder y Revolución en México, 1911-1920 (México: FCE, 1985), 109; Berta Ulloa, Veracruz, capital de la nación (1914-1915) (México: El Colegio de México / Gobierno del Estado de Veracruz, 1986), 108.

47 El Pueblo, "Sigamos a Carranza para honrar a Juárez" (21 de marzo de 1915): 3.

48 Ibid., "Triunfó el ejército constitucionalista" (8 de abril de 1915): 1; El Demócrata, "Extra" (8 de abril de 1915): 1. 
Carranza, de cuyo lado estaba la "Justicia", ${ }^{49}$ mientras que con Villa huían, además de sus correligionarios, más de cien curas. ${ }^{50}$

Así fue como los carrancistas hicieron crecer el panteón de los "villanos y traidores", con Villa, Ángeles y Zapata, debido a que los viejos ideales por los cuales habían luchado en 1910 ya no eran más sus metas ni sus razones para pelear.

Todos juntos no acariciaron un ideal noble, no tuvieron orientación política y ese anhelo santo que vive y se agita en el alma del revolucionario puro, consciente y convencido; es por esto que cuando esa trilogía oyó la primera clarinada, de la reacción que se agazapaba en los rincones, acudió presurosa, alucinada, por el oro que derramaban en sus bolsillos la casta de privilegiados amamantados por Díaz; por el alto clero, principalmente extranjero, que suspira por los felices tiempos de su dominación. ${ }^{51}$

La nota culminaba, una vez más, con un llamado a los hombres que seguían a Carranza para que redoblasen esfuerzos y evitar así el regreso al yugo "de la tutela clerical" y exterminaran a la reacción de una vez por todas: "o se aplasta para siempre la hidra de la reacción o regresamos vergonzosamente al pasado. He aquí el dilema".

El editorial carrancista aseguraba que ni Villa, que abrazaba a los oficiales porfiristas y huertistas, ni Zapata buscaban llevar a cabo las reformas sociopolíticas necesarias, y en cambio se agrupaban en torno a los viejos enemigos. Contrario a ello: "en su anhelo por la libertad, el pueblo volvió a agruparse en derredor de su nuevo Apóstol, volvió la justicia después de sangrientas luchas a triunfar de la maldad y fue el señor Carranza quien continuó el ciclo de libertad y de justicia en México". Debía romperse la "Ley del Retorno":

Por todo lo expuesto, no cesaremos de señalar el peligro; por lo mismo, no perderemos oportunidad de recomendar a la gente honrada mucha cordura en todos sus actos y procedimientos, a fin de que no surjan entre nosotros mismos, escisiones que retardarían la resolución definitiva del trascendental problema que tiene el Gobierno Constitucionalista.

\footnotetext{
${ }^{49}$ El Pueblo, "La Justicia está con nosotros. Sobre la victoria de ayer" (9 de abril de 1915): 3.

${ }^{50}$ Méndez Lara, "La propaganda como arma...", 72-76, 82.

${ }^{51}$ El Pueblo, "Los privilegios y el despotismo de los de arriba ocasionó la rebelión de los de abajo. LA LEY DEL RETORNO" (7 de abril de 1915): 3.
} 
No busquemos la oportunidad de que se cumpla una vez más la fatal, la bárbara Ley del Retorno. ${ }^{52}$

El 11 de abril se publicó otro editorial que ejemplifica a la perfección la construcción del enemigo y la exageración de los hechos durante las batallas: "he visto alguna vez caer un tigre herido, al fondo de un barranco, en su precipitado descenso, ramajes, piedras, hojarasca y polvo en torbellino turbulento; algún momento lo vi sostenerse, y ya parecía que lograba rehacerse, cuando la rama a que asido se quedara desgajándose rápida, precipitó al animal hacia el profundo abismo". El "tigre herido" Villa sucumbía junto con los viejos enemigos del estado liberal mexicano, "el clericalismo, el cientificismo y exfederalismo". ${ }^{53}$

Un segundo choque en Celaya se llevó a cabo del 13 al 15 de abril, pero en esta ocasión Obregón se había reforzado con unos 15 mil hombres, mientras Villa fue fortalecido por fuerzas provenientes del norte y algunos contingentes de Michoacán, Jalisco y San Luis Potosí. ${ }^{54}$ Una vez más "el genio" de Obregón triunfó. El Pueblo exaltó las acciones del sonorense, quien conocía con detalles los planes del "traidor"; los villistas, "fieles a su costumbre", fracasaron en todos sus asaltos. ${ }^{55}$ Los carrancistas tuvieron una victoria "arrolladora" y al grito de "sálvese quien pueda" huyeron los hombres de la "invencible" División del Norte; en palabras de Juan Barragán: "Ios leones" habían mutado en "mansos corderos".56

Por esos mismos días en la prensa carrancista se rumoró sobre una fractura en el seno del bando villista. Afirmaron que Felipe Ángeles era prisionero de Villa y poco después dijeron también que Ángeles había abandonado a Villa debido a que no compartían ideales. Paralelamente se difundió que diversas "bandas" de exfederales-huertistas formadas en Estados Unidos estaban a punto de ingresar al país para batir a los villistas; la prensa consignó que los rebeldes recibían un salario de los bolsillos de los científicos porfiristas, ${ }^{57}$ de ahí que la primera plana del 18 de mayo asegurara que "Los científicos después de tomar por instrumento a Villa, vuelven sus armas contra él". ${ }^{58}$ El objetivo era evidente,

\footnotetext{
$52 \mathrm{lbid}$

${ }_{53}$ Ibid., "En el campo villista tocan a muerte", por A.P.R. (11 de abril de 1915): 3.

54 Obregón, Ocho mil kilómetros, 327.

55 El Pueblo, "Ha triunfado el Ejército Constitucionalista" (16 de abril de 1915): 1.

56 Juan Barragán Rodríguez, Historia del Ejército y de la Revolución constitucionalista, t. 2 (México: INEHRM, 1985), 295-296.

${ }^{57}$ El Pueblo, "Se asegura que Ángeles es prisionero de Villa" (13 de mayo de 1915): 1.

${ }^{58}$ Ibid., "Los científicos después de tomar por instrumento a Villa, vuelven sus armas contra él" (18 de mayo de 1915): 1.
} 
querían mostrar cómo los enemigos se enfrentaban entre sí, mientras los carrancistas ganaban batallas e incrementaban su fuerza. ${ }^{59}$

Según la prensa carrancista, la causa villista cavó su tumba, su poder sólo había sido temporal debido a que el "Dios del crimen Villa" los ayudaba. Las victorias en Celaya dieron a los carrancistas la pauta para desprestigiar al duranguense con mayor ahínco: Doroteo Arango alias Pancho Villa, el "indomable Atila del Norte", el "Napoleón bandido", había comprendido "su miserable organismo microbiano". Por su lado, Obregón, el "ilustre" general constitucionalista que llevaba "en sus venas la brava sangre yaqui, tuvo a bien sacudirse el polvo de su casaca con la hirsuta melena de la testa del nunca bien ponderado Doroteo Arango". 60

Tras las derrotas en Celaya, Villa se percató de "su pequeñez espantosa [...] sintió sed de sangre y se lanzó a la batalla, pero ni para beber savia roja, por las heridas abiertas de los enemigos, sino para llorar como mujer cobarde e impotente ante el domador que le latigueaba las ancas". ${ }^{61}$ El antes "gigante" e invencible Villa se transformó en un "pigmeo".

El sábado 15 de mayo de 1915 un texto de Moisés Suárez, "Cuatro meses de régimen villista", mostró las dificultades de vivir bajo "el yugo villista" para confrontar las vivencias del pueblo, que sobrevivía bajo el control de los reaccionarios y quienes lo hacían "bajo la sombra protectora" del carrancismo. Los ejemplos fueron dos: Coahuila y Monterrey, en donde la población había mostrado su desaprobación y temor: desde que las tropas villistas ocuparan su territorio: "La gente gritaba ‘ ¡Desgraciados! Ustedes nos están matando. Con Carranza nunca tuvimos hambre...". . De forma moralizadora terminaba la nota: "Los ilusos de Saltillo y Monterrey, hoy han visto a Villa desenmascarado, vuelven la mirada hacia el constitucionalismo, como la tabla salvadora, y el pueblo medio que en triunfo o en derrota ha sido siempre 'carrancista' espera impaciente la hora en que el ejército de la legalidad levante la afrenta del villismo que sobre ambas capitales pesa".62 Este tipo de ataques contra el villismo fueron fortalecidos con notas editoriales que aseguraban el orden de las zonas dominadas por el carrancismo, en donde además se continuaba comparando a Carranza

\footnotetext{
59 Ibid., "Los villistas se repliegan a Aguascalientes". Esos días se publicaron otros editoriales similares, como "La agonía de los científicos" (13 de mayo de 1915): 3.

60 Ibid., "El fracaso final" (17 de mayo de 1915): 3.

${ }^{61} \mathrm{lbid}$.

${ }^{62}$ Moisés Suárez, "Cuatro meses de régimen villista", El Pueblo (15 de mayo de 1915): 3.
} 
con Juárez e incluso con Hidalgo, como hombres que velaron por las libertades sociales. ${ }^{63}$

Una semana más tarde El Pueblo reprodujo un "retrato" de la reacción redactado por el director de El Eco de México en Los Ángeles, California, Carlos Félix Díaz, quien resume con detalles el tema de los traidores y enemigos no sólo de la Revolución que se vivía, sino a lo largo de la historia de México. Para el autor, la "reacción" era:

una fuerza de inercia que pugna constantemente contra otra fuerza contraria que desenvuelve, activa y pone en movimiento a todas las cosas hacia adelante, fuerza que se define con esta palabra: Progreso. De esto resulta que la reacción y el progreso son enemigos jurados. Nosotros asegurémonos que la reacción es un obstáculo que constantemente está salvando el progreso. El combate de la reacción contra el progreso, es decir, contra la evolución en espiral ascendente de todas las cosas, se libra en todas, en todos los elementos y en todos los órdenes. En lo moral encontramos a estos dos irreconciliables enemigos luchando, así en lo intelectual, en lo físico, en lo político y en lo

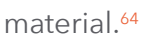

Este autor analizó lo "reaccionario" en México en el orden político desde los tlaxcaltecas, pasando por Iturbide y hasta llegar a los casos de Orozco, pero especialmente se detuvo en el actual, es decir, en el relativo a Villa y Zapata. Cuando argumenta contra Villa, lo hace confrontando la idea de progreso, representado por los carrancistas, y el bando apoyado por los científicos, el de Villa-Zapata; por ende, si apoyaban a los hombres del antiguo régimen no podían ser considerados revolucionarios, sino simplemente reaccionarios.

Los actos de Villa para ser considerado aliado de la reacción eran, principalmente, llamar a los exfederales "amigos", empezando con el propio Felipe Ángeles, que había sido desleal al primer mando. Asimismo, se atacó su nulo interés para llevar a cabo reformas sociales: Villa, "ni su gobierno han lanzado programa revolucionario alguno, ni siquiera han esbozado leyes o decretos que tiendan a mejorar la condición del pueblo", aseguró la prensa carrancista. Por el contrario, toda su aspiración se reducía a restablecer "el orden constitucional" tal como se encontraba en épocas pasadas. "Orden constitucional que resulta un sarcasmo.

${ }_{63}^{6}$ El Pueblo, "La moralidad de los gobernadores constitucionalistas" (3 de junio de 1915): 3.

${ }^{64}$ Carlos Félix Díaz, "Qué se entiende por reacción y quienes la constituyen en México", El Pueblo (22 de mayo de 1915): 3. 
Ya lo sabemos todos: el pueblo no quiere orden constitucional mientras haya orden económico". Además, Carlos Félix añadió la lista de otros exfederales enlistados en las filas villistas. ${ }^{65}$ Dadas las "pruebas", Ilamaba a quien no pudiera aceptar que el villismo era la "reacción" pura, a reconsiderar su postura.

Los contrastes fueron notablemente marcados y bien definidos durante este mes: de un lado estaba representada la justicia, los principios liberales, la patria, y del otro "una turba de salteadores, una legión de tinterillos famélicos llevando a la retaguardia bien ocultos, pero incansables a todos los agentes de la reacción clásica, a los frailes que falazmente se envuelven en la túnica de los dogmas religiosos para hacerse inmunes, como si no mediase un abismo entre el dogma y el cura".66

Villa, al estar vinculado con la reacción y ser su último reducto, no podía ser quien llevase las riendas de la nación, por ello no podía salvar a la patria en ese momento tan importante, aseveró El Pueblo. ${ }^{67}$ Conforme avanzó la lucha armada, los embates se hicieron más directos; en junio lo compararon directamente con Victoriano Huerta, las "panteras triunfadoras" del siglo XX, e incluso aseguraron que debían ser examinados bajo las técnicas lombrosianas, dadas sus características tan peculiares. Villa era el tipo de "hombre primitivo, de ese hombre primitivo eslabonado, darwinianamente, con el mono. En su frente estrecha se refleja el asnal prodigio de su célula. El miraje moral que Doroteo Arango nos presenta es espantoso. Gusta beber sangre en cráneos frescos. El rasgueo del puñal al penetrar por la espalda de cualquier víctima le transporta". ${ }^{68}$ Lo tacharon de imbécil debido a que tenía el complejo de sentirse gigante "en su misma pequeñez", demostrada ante los cañones de Obregón. Por otra parte, a Huerta sólo le dedicaron unas pocas líneas; en conclusión, la nota aseguró que

${ }^{65} \mathrm{El}$ autor asegura que colaboraron con Villa y Zapata los siguientes generales militares exfederales: Felipe Ángeles (lugarteniente de Villa), Pedro Ojeda, Eduardo Ocaranza, José Delgado, Alberto T. Rasgado, Juvencio Alessio Robles [sic], Samuel García Cuéllar, Santiago F. Riveros (que últimamente era administrador del periódico villista El Norte) e Higinio Aguilar. "Como cuerpos organizados a las órdenes de Villa tenemos al 25 batallón exfederal integrado en su totalidad por elementos del pasado. Desde el soldado raso hasta su Jefe que lo es el coronel Esteban Cantú. Este batallón opera en el Distrito Norte de la Baja California. Batería Fija exfederal con todo y su personal trasladada en el mes de octubre del año pasado a Sonora por orden de Villa y donde sigue operando bajo las órdenes del teniente coronel exfederal Fortunato Tenorio", Ibid.

${ }^{66}$ El Pueblo, "La última lamentación de Roque" (30 de mayo de 1915): 3.

${ }^{67} \mathrm{Ibid}$., "Quiénes son los responsables de la angustiosa situación de México" (29 de mayo de 1915): 1.

68 Ibid., "Huerta y Pancho Villa" (5 de junio de 1915): 3. 
a ambos los había engendrado "la traición en el vientre del crimen". La ciencia también fungió como apoyo en la labor de desprestigio carrancista.

En la misma sintonía, en una nota editorial de El Demócrata criticaron la forma en que Ángeles y Villa habían "explotado el fanatismo" de las personas que querían atraer. En dichas líneas se tildó de científico a Ángeles, quien se había atraído al "bruto y relajado, analfabeto y bandido" Doroteo Arango. ${ }^{69}$

En la estación Trinidad, cerca de León, Guanajuato, se desarrollaba paralelamente otro enfrentamiento entre villistas y carrancistas, que vio su fin durante los primeros días de junio de 1915. En un extra de El Demócrata se dio por primera vez la noticia de la victoria carrancista sobre Villa en León, Guanajuato. ${ }^{70}$ Por su parte, El Pueblo difundió el triunfo de la siguiente forma: "El más importante triunfo alcanzado por las armas constitucionalistas" y enalteció la actuación de Obregón y sus hombres, quienes luchaban "encarnizadamente" desde semanas atrás contra los hombres liderados por Villa y Ángeles. ${ }^{71}$ Dos días después un editorial afirmaba que la reacción había recibido el golpe de gracia, "el tigre" Pancho Villa no sólo estaba malherido, sino moribundo:

Doroteo Arango (a) Pancho Villa, como un tigre herido fugado de su jaula, va dejando a su paso una huella de sangre. El domador le persigue de cerca y la jaspeada bestia empieza a sentir el desvanecimiento de la fuerza que se fuga. La embestida fue colosal; pero Álvaro Obregón, el domador de fieras zapatovillistas, descargó muy fuerte sus látigos, tan fuerte que el tigre chihuahuense, espalda al domador, se fugó dejando en la arena a sus cachorros. ${ }^{72}$

El 14 de junio, un par de días después de que fue publicado el "manifiesto de Carranza" en el que aseguraba que la Revolución había terminado, El Pueblo publicó un editorial que plasmó el resultado de una serie de notas que buscaron construir una imagen favorable de los generales de la facción carrancista, llevó por título "Los héroes" y retomó el frecuente argumento según el cual sólo

${ }^{69}$ El Demócrata, "Explotando el fanatismo", por Ejoff (2 de junio de 1915): 1.

70 Ibid., "Los soldados del Gral. Obregón derrotaron a Fco. Villa" (6 de junio de 1915): 1.

${ }^{71}$ La nota agregaba: "Al felicitarlo ahora por el más importante triunfo con que ha cubierto usted de gloria a las armas constitucionalistas, puedo asegurar a usted que no está lejano el día en que restablezcamos la paz y el orden de la República, sírvase usted en aceptar mi más calurosa felicitación por el importante hecho de armas de ayer, y hacerla extensiva a los generales, jefes, oficiales y tropa por su heroico comportamiento", véase El Pueblo, "La reacción ha recibido el golpe de gracia" (7 de junio de 1915): 1.

72 Ibid., "Periodo de expectación" (8 de junio de 1915): 3. 
los hombres que tenían verdaderos ideales por los cuales pelear podían erigirse con el triunfo que los haría inmortales ante la historia:

En donde se encuentra un don Venustiano Carranza, entregando un hermano querido a la muerte, antes que tener una transacción política o una aplicación de principios. [...] en donde se encuentre un general Álvaro Obregón que, de cara a la muerte y en los dolores acerbos de un brazo arrancado por enemiga metralla bendiga a la revolución, por la que ha dado tranquilidad y juventud y espere el último instante con palabras de regocijo por entregarse en holocausto a la Patria; en donde se encuentren los héroes que no se doblen ante la muerte ni ante el dolor, ahí está el buen camino, el camino de la verdad, el camino de la Justicia, el camino de la Gloria. ${ }^{73}$

Empero, además de Carranza, el verdadero héroe era el hombre que derrotó a Villa en el Bajío, quien "vivirá en las páginas escritas con heroica sangre, entusiasta ante la muerte y diciendo, en la agonía de su cuerpo mutilado, al bravo general Murguía: Diga usted a nuestro Primer Jefe que he caído cumpliendo con mi deber, y que muero bendiciendo a la revolución". La labor por destacar a Obregón se mantuvo a lo largo de los últimos días de junio en diversas editoriales y noticias aparecidas en El Pueb/o. ${ }^{74}$

Llegada esta fecha, Francisco Villa comenzaba a mostrar un rechazo enorme contra los periodistas debido a las múltiples mentiras y versiones que se crearon en torno suyo durante esta época, muy lejos de aquellas historias de invencibilidad difundidas años atrás. Con el triunfo de Venustiano Carranza, los periódicos quedaron bajo su dominio y las versiones sobre el Centauro del Norte y del villismo en general continuaron nutriendo aquella "leyenda negra".

\section{Conclusiones}

Pancho Villa, como hemos podido observar, fue retratado de diversas formas a lo largo de la lucha armada. Sus leyendas y la construcción de su imagen son indivisibles de su vida y deben entenderse para comprender al personaje en sus múltiples facetas.

\footnotetext{
73 Ibid., "Los héroes" (14 de junio de 1915): 3.

${ }^{74}$ Otro ejemplo de esto fue "Dos épocas y dos hombres", en el mismo diario (22 de junio de 1915): 1.
} 
La prensa carrancista, dirigida y difundida principalmente entre sus partidarios y leída en menor medida por la escasa población lectora del país, construyó una imagen negativa de Villa con el fin de impulsar una campaña de desprestigio contra el duranguense, pero también para denigrar el proyecto revolucionario de la Convención. Los artículos, notas y editoriales sobre Villa aparecieron todos los días en los periódicos carrancistas; su denostación y crítica formó parte de la cotidianidad de estas publicaciones. Muchas ocasiones Villa y su ejército fueron tema de la primera plana, aunque ello no significaba que no aparecieran también en la tercera página, en las notas de opinión y en el propio editorial. Realizar una contabilidad exhaustiva de esas notas rebasaba el objetivo de este trabajo, pero a guisa de ejemplo basta mencionar que El Pueblo, entre el 1o. de octubre de 1914 y el 7 de junio de 1915, contó con dos o tres menciones del revolucionario en cada uno de sus números (243), siendo enero-mayo de 1915 los meses durante los que la propaganda antivillista se incrementó y en ocasiones el Centauro del Norte fue mencionado más de cinco veces en sus páginas. Esto reflejó diversas estrategias de propaganda para desprestigiar al principal líder revolucionario del bando contrario. Algo que resulta llamativo es el escaso uso de las imágenes para atacar al divisionario norteño, fue escasa la publicación de fotografías o litografías de Villa, por ello no se analizaron ni se echó mano de ellas, ya que algunas de las que se incluyeron al parecer formaban parte del archivo de imágenes que los carrancistas conservaron de periódicos como El Imparcial y databan de 1913 y de los primeros meses de 1914.

En un primer momento los periódicos carrancistas se dedicaron a remarcar que Villa era el enemigo a vencer, a diferencia de Emiliano Zapata, quien fue en muchas ocasiones menospreciado por la prensa de la época debido a que, en apariencia, tenía un limitado poder militar. Posteriormente, una vez enfocado el enemigo, se construyó su imagen como la de aquel bandido que no controlaba sus impulsos y se dejaba guiar, como marioneta, por los principales grupos del antiguo régimen, adversarios del liberalismo mexicano, los militares, exfederales porfiristas-huertistas, y el clero. Villa era la encarnación de la reacción.

Más adelante la dinámica de desprestigio del enemigo cobró un peso fundamental en la intentona de la prensa carrancista para buscar la supremacía frente a los villistas durante la etapa más álgida de la lucha armada. Villa, el revolucionario "invencible", fue transformado en el "Napoleón bandido" y el "Atila del Norte" que, tras sus fracasos en el Bajío, fue denigrado a "tigre herido" y pig- 
meo. Es de gran importancia resaltar que las denominaciones que se le dieron a Villa, como parte de una "Trinidad maldita", "Napoléon bandido" o el propio "tigre domado" o "herido", tienen una connotación denigrante, pero en el fondo demuestran respeto y superioridad. La "trinidad" tiene un trasfondo evidentemente religioso (Dios padre, Hijo y Espíritu Santo); Napoléon se caracterizó por ser el líder del ejército francés y un gran estratega militar, lo cual le permitió consolidar un imperio. Por su parte, el tigre como mote de bandidos sociales no era nuevo en lo absoluto, basta recordar a Manuel Lozada, "el tigre de Alica", quien fue un dolor de cabeza para el presidente Benito Juárez en el occidente del país y un líder carismático en la región que dominó.

La construcción de la imagen de Francisco Villa en la prensa carrancista puede considerarse uno de los pilares de lo que Katz estima la "leyenda negra" del caudillo, en la cual es retratado como un bandolero inmoral, un abigeo salvaje que nunca había podido dejar atrás su pasado y cometía hechos atroces en contra de sus enemigos. La asimilación de Villa en el panteón de los héroes nacionales - una parte de sus restos fueron colocados en el monumento a la Revolución en la década de 1970-, que retoma parcialmente las leyendas "épica" y "blanca" de Villa, y su innegable impacto en el imaginario popular como un líder de la revolución social, han permitido que en la actualidad aquella imagen de bandido se haya difuminado con el paso del tiempo.

Menospreciar o soslayar el impacto de la prensa durante la Revolución mexicana sería pasar de largo un factor fundamental en la construcción de la propia guerra y de sus protagonistas en aquel momento. Sería dejar en el olvido el eco del pasado que nos construyó y reconstruye.

\section{Referencias}

Alessio Robles, Vito. La Convención Revolucionaria de Aguascalientes. México: Instituto Nacional de Estudios Históricos de la Revolución Mexicana, 1979. Amaya, Luis Fernando. La Soberana Convención Revolucionaria, 1914-1916. México: Editorial Trillas, 1966.

Arenas Guzmán, Diego. El periodismo en la Revolución mexicana. 2 tomos. México: Instituto Nacional de Estudios Históricos de la Revolución Mexicana, 1967.

Ávila Espinosa, Felipe Arturo. El pensamiento económico, político y social de la Convención de Aguascalientes. México: Instituto Nacional de Estudios 
Históricos de la Revolución Mexicana / Instituto Cultural de Aguascalientes, 1991.

Barragán Rodríguez, Juan. Historia del Ejército y de la Revolución constitucionalista. Tomo 2. México: Instituto Nacional de Estudios Históricos de la Revolución Mexicana, 1985.

Berumen, Miguel Ángel. Pancho Villa: la construcción del mito. México: Océano, 2009.

Ceballos, Ciro B. "Editorial. Los inquisidores del Villismo". El Liberal (25 de noviembre de 1914).

Cervantes, Federico. Francisco Villa y la Revolución. México: Alonso, 1960.

La Convención. Diario Identificado con los Ideales de la Soberana Convención Revolucionaria y Reproductor de los Debates de todas sus Sesiones. Aguascalientes; San Luis Potosí; México, D. F.; Cuernavaca (noviembre de 1914 - julio de 1915).

Cronlund Anderson, Mark. Pancho Villa's Revolution by Headlines. Oklahoma: University of Oklahoma Press, 2000.

El Demócrata. Diario Constitucionalista. México D. F.; Veracruz (agosto-noviembre de 1914).

Díaz, Carlos Félix. "Qué se entiende por reacción y quienes la constituyen en México". El Pueblo (22 de mayo de 1915).

Domenach, Jean Marie. La propaganda política. Buenos Aires: Editorial Universitaria, 1962.

García, Clara Guadalupe. El Imparcial. Primer periódico moderno de México. México: Centro de Estudios Históricos del Porfiriato, 2003.

Garciadiego, Javier. "La prensa durante la Revolución mexicana". En Las publicaciones periódicas y la historia de México (ciclo de conferencias). Coordinación de Aurora Cano Andaluz, 71-88. México: Universidad Nacional Autónoma de México, 1995.

Hall, Linda B. Álvaro Obregón. Poder y Revolución en México, 1911-1920. México: Fondo de Cultura Económica, 1985.

Herrera, Alfonso. "Carranza o Zapata y Villa". El Liberal (8 de marzo de 1915).

Herrera, Maclovio. "Francisco Villa exhibido de cuerpo entero". El Pueblo (6 de diciembre de 1914).

El Imparcial. Diario llustrado de la Mañana. México, D. F. (junio-agosto de 1914). Katz, Friedrich. Pancho Villa. 2 vols. México: ERA, 2000.

Lagos Cházaro, Francisco y Juan Antonio Acosta. "Hechos y razones contra las calumnias de A. Obregón". La Convención (16 de febrero de 1915). 
El Liberal. Diario de la Mañana. México, D. F. (agosto-noviembre de 1914).

Martínez, Rafael. "El Caso Villa". El Liberal (26 de octubre de 1914).

Matute Aguirre, Álvaro. "Prensa, sociedad y política (1911-1916)". En Las publicaciones periódicas y la historia de México (ciclo de conferencias). Coordinación de Aurora Cano Andaluz, 64-70. México: Universidad Nacional Autónoma de México, 1995.

Méndez Lara, Francisco Iván. "La propaganda como arma de guerra en la Revolución mexicana. Las Batallas del Bajío (1915)". Revista Internacional de Historia de la Comunicación, núm. 7 (2016): 67-91. http://dx.doi.org/10.12795/ RiHC.2016.i07.04.

Méndez Lara, Francisco Iván. “¿Una querella silenciosa? La guerra de papel en los inicios de la lucha de facciones: el caso carrancista (agosto-diciembre de 1914)". Letras Históricas, núm. 10 (primavera-verano 2014): 115-148.

Méndez Lara, Francisco Iván. "¡Vámonos para Veracruz! La prensa carrancista y su proyecto revolucionario. Del puerto a la Ciudad de México (noviembre 1914 - marzo 1915)". Ulúa. Revista de Historia, Sociedad y Cultura, núm. 24 (2014): 145-176.

Méndez Lara, Francisco Iván. "Venustiano Carranza y la prensa. Un panorama periodístico, 1913-1919". Caleidoscopio. Revista de Ciencias Sociales y Humanidades, núms. 35-36 (2016-2017): 103-143.

El Monitor. Diario de la Mañana. México, D. F. (diciembre de 1914 - mayo de 1915).

Obregón, Álvaro. Ocho mil kilómetros en campaña. México: Fondo de Cultura Económica, 1960.

El País. Diario de la Mañana. México, D. F. (22 de agosto de 1914).

Palacio Montiel, Celia del, coordinación. Prensa, revolución y vida cotidiana en Veracruz, 1910-1915. Xalapa: Universidad Veracruzana, 2012.

Palavicini, Félix F. "El crepúsculo de los dioses". El Pueblo (2 de diciembre de 1914).

Palavicini, Félix F. "Las máscaras del Diablo". El Pueblo (12 de enero de 1915).

El Pueblo. Diario de la Mañana. México D. F.; Veracruz (octubre-noviembre de 1914; diciembre de 1914 - junio de 1915).

Q. Mendoza, Gerardo. "El periódico El Pueblo y la propaganda política carrancista (octubre de 1914 - enero de 1915)". Bibliographica, vol. 2, núm. 2 (segundo semestre 2019): 131-170. https://doi.org/10.22201/iib.biblio graphica.2019.2.51.

Quirk, Robert E. La Revolución mexicana, 1914-1915. México: Azteca, 1962. 
Ramírez Hurtado, Luciano. Imágenes del olvido, 1914-1994. Discurso visual, manipulación y conmemoraciones de la Convención Revolucionaria de Aguascalientes. Aguascalientes: Universidad Autónoma de Aguascalientes, Centro de Ciencias Sociales y Humanidades, 2010.

Reed Torres, Luis y María del Carmen Ruiz Castañeda. El periodismo en México: 500 años de historia. México: Edamex, 2002.

Rodríguez Kuri, Ariel. Historia del desasosiego. La Revolución en la Ciudad de México, 1911-1922. México: El Colegio de México, Centro de Estudios Históricos, 2010.

Rutherford, John. La sociedad mexicana durante la Revolución. México: El Caballito, 1973.

Salmerón Sanginés, Pedro. 1915. México en guerra. México: Planeta, 2015.

Suárez, Moisés. "Cuatro meses de régimen villista". El Pueblo (15 de mayo de 1915).

El Tiempo. México, D. F. (febrero de 1912).

Ulloa, Berta. La encrucijada de 1915. México: El Colegio de México, 1979.

Ulloa, Berta. La revolución escindida. México: El Colegio de México, 1979.

Ulloa, Berta. Veracruz, capital de la nación (1914-1915). México: El Colegio de México / Gobierno del Estado de Veracruz, 1986.

Useta, Jorge. "Al margen de los sucesos diarios". El Pueblo (13 de enero de 1915).

Valadés, José C. Historia general de la Revolución mexicana. 5 tomos. México: Secretaría de Educación Pública / Gernika, 1985.

Villa Guerrero, Guadalupe. "Pancho Villa en el imaginario popular". En Revolución y exilio en la historia de México: del amor de un historiador por su patria adoptiva. Homenaje a Friedrich Katz. Coordinación de Javier Garciadiego y Emilio Kouri, 403-411. México: El Colegio de México / ERA / The University of Chicago / Centro Katz de Estudios Mexicanos, 2010. 